\title{
BMJ
}

\section{Treatment of human brucellosis: systematic review and meta-analysis of randomised controlled trials}

\author{
Keren Skalsky, student , 'Dafna Yahav, resident , ' Jihad Bishara, head of unit , 2,3 Silvio Pitlik, head of \\ department, 2,3 Leonard Leibovici, head of department, ,,3 Mical Paul, senior physiciann ${ }^{2,3}$
}

IInternal Medicine E, Rabin Medical Center, Beilinson Hospital, Petah Tikva 49100, Israel

${ }^{2}$ Infectious Diseases Unit, Rabin Medical Center, Beilinson Hospital

${ }^{3}$ Sackler Faculty of Medicine, Tel-Aviv University, Ramat Aviv 69978, Israel

Correspondence to: M Paul pil1pel@zahav.net.il

doi:10.1136/bmi.39497.500903.25

\section{ABSTRACT}

Objectives To determine and quantify differences in efficacy between treatment regimens for brucellosis. Design Systematic review and meta-analysis of randomised controlled trials assessing different antibiotic regimens and durations of treatment for human brucellosis.

Data sources PubMed, CENTRAL, Lilacs, conference proceedings, and bibliographies with no restrictions on language, study year, or publication status.

Review methods Search, application of inclusion and exclusion criteria, data extraction, and assessment of methodological quality independently performed in duplicate. Primary outcomes were relapse and overall failure resulting from primary failure or relapse. Relative risks with $95 \%$ confidence intervals were calculated and pooled with a fixed effect model.

Results 30 trials and 77 treatment arms were included. Overall failure was significantly higher with doxycyclinerifampicin compared to doxycycline-streptomycin, mainly due to a higher rate of relapse (relative risk $2.80,95 \%$ confidence interval 1.81 to $4.36 ; 13$ trials, without heterogeneity). Results were consistent among patients with bacteraemia and complicated brucellosis. Doxycycline-streptomycin resulted in a significantly higher rate of failure than doxycycline-rifampicinaminoglycoside (triple drug regimen) $(2.50,1.26$ to 5.00 ; two trials). Gentamicin was not inferior to streptomycin (1.45, 0.52 to 4.00 for failure; two trials). Quinolones combined with rifampicin were significantly less effective than doxycycline combined with rifampicin or streptomycin (1.83, 1.11 to 3.02, for failure; five trials). Monotherapy was associated with a higher risk of failure than combined treatment when administered for a similar duration (2.56, 1.55 to 4.23; five trials). Treatment for six weeks or more offered an advantage over shorter treatment durations.

Conclusions There are significant differences in effectiveness between currently recommended treatment regimens for brucellosis. The preferred treatment should be with dual or triple regimens including an aminoglycoside.

\section{INTRODUCTION}

Brucellosis is the commonest zoonotic infection worldwide. More than 500000 new cases occur annually but with an uneven global distribution. Yearly incidence rates range from 0.3 cases per million in the United Kingdom and most parts of the United States to above 1 case per 1000 in endemic regions, where the disease represents a considerable and increasing health burden. ${ }^{1}$

Treatment is given to shorten the duration of symptoms, prevent relapse, and avert complications such as arthritis, sacroiliitis, spondylitis, encephalitis, endocarditis, epididymoorchitis, and abortion. ${ }^{2}$ Because monotherapies were historically characterised by high rates of relapse, a combination of two drugs is currently used. ${ }^{3}$ Recommendations for specific regimens in reference sources are inconsistent. Guidelines of the World Health Organization, last published in 1986, recommended doxycycline with rifampicin for six weeks in place of their previously recommended regimen of tetracycline for six weeks in combination with streptomycin for the first two to three weeks. ${ }^{4}$ The relative merits of these two regimens are still being discussed.$^{5-8}$ Alternative treatments include other antibiotics, such as fluoroquinolones and co-trimoxazole and their combinations with rifampicin. Recent consensus recommendations of an expert panel proposed doxycycline-streptomycin and doxycycline-rifampicin as first line regimens, without quantifying the differences between them. ${ }^{9}$

A previous meta-analysis, including six trials that were published up to 1992, found that doxycyclinestreptomycin was superior to doxycyclinerifampicin. ${ }^{10}$ Since then, many more trials assessing the WHO recommended regimens have been published. Recent trials assessed the effect of quinolone based combination therapy and triple drug regimens. Streptomycin has been replaced by newer aminoglycosides and their effects on brucellosis have not been summarised. Finally, the advantage of combination therapy over monotherapy has not been quantified.

We performed a systematic review and metaanalysis of all randomised controlled trials that assessed different antibiotic regimens for the treatment of brucellosis to identify the optimal treatment regimen and duration of treatment and to obtain quantitative estimates of effect for the difference between existing regimens. 


\section{METHODS}

We included randomised or quasi-randomised controlled trials that tested any single or combination antibiotic treatment for Brucella infections compared with placebo, no treatment, or another antibiotic regimen (different drugs or different duration of treatment). We included trials in adults or children with documented infections caused by Brucella spp. Documented brucellosis was defined as positive results in blood or bone marrow cultures or clinical manifestations with a history of exposure and serological confirmation. We included patients with uncomplicated and complicated brucellosis.

Our four predefined comparisons were any tetracycline combined with any aminoglycoside versus any tetracycline combined with rifampicin or its derivatives; combination regimens with a quinolone versus combination regimens without quinolones; any combination of drugs versus any monotherapy (co-trimoxazole was considered as monotherapy); and combination treatment administered for 30 days or less versus six weeks or longer.

Our two predefined primary outcomes were relapse, defined as re-appearance of symptoms, development of clinical complications, rise in antibody titres or positive results on cultures after the end of treatment, during the trials' follow-up; and "overall failure," defined as either therapeutic failure or relapse, where therapeutic failure was defined as persistence of signs or symptoms beyond the trial's defined period of expected response or modification of assigned treatment regimen because of perceived failure of treatment.

Secondary outcomes included therapeutic failure, defined as above; development of complications of disease that were not present initially; all cause mortality at the end of follow-up; any discontinuation of treatment, defined as the need for premature discontinuation or modification of the study drug/s because of inefficacy or side effects; and any adverse events, including those necessitating discontinuation or modification of treatment, renal failure, ototoxicity and hepatotoxicity as defined in study, gastrointestinal intolerance, and dermatological reactions.

\section{Search strategy}

We conducted a comprehensive search to identify all relevant studies regardless of language, publication status, or year of publication. We combined the terms ("Brucella"[MeSH] OR "Brucella suis"[MeSH] OR "Brucella abortus" [MeSH] OR "Brucella melitensis"[MeSH] OR brucel*) with the Cochrane's sensitive search strategy for randomised controlled trials. ${ }^{11} \mathrm{We}$ searched in CENTRAL (Cochrane Library, issue 3, 2007); PubMed and LILACS (up to June 2007). We also searched conference proceedings for unpublished trials including the Interscience Conference on Antimicrobial Agents and Chemotherapy 1995-2007, the European Congress of Clinical Microbiology and Infectious Diseases 2001-7, and the Annual Meeting of the Infectious Diseases Society of America 2001-7.
We searched trial registries for ongoing and unpublished trials. Finally, we scanned the references of all included and excluded trials to identify additional trials.

Two reviewers (KS, DY) performed the search and applied inclusion criteria. The same reviewers independently extracted data from included trials on to a data extraction sheet. Differences in the data extracted were resolved by discussion with a third reviewer (MP). We extracted data on methodological quality of included trials; demographics and patients' characteristics; Brucella species, diagnosis and follow-up; and outcome data with definitions. We contacted authors of each included study for clarifications and missing outcome data. Outcomes were extracted preferentially by intention to treat, including all individuals randomised in the outcome assessment.

We calculated relative risks for dichotomous data, with $95 \%$ confidence intervals. We pooled trials comparing similar regimens, subcategorised by the type of antibiotics included in each comparison and duration of treatment. Numbers needed to treat (NNT) were calculated as $1 /$ risk difference obtained from a meta-analysis of the trials. Analyses were performed using RevMan version 4.2.10.

We assessed methodological quality using the individual component approach for generation of allocation sequence, concealment of allocation, blinding, intention to treat analysis, and number of patients excluded from outcome assessment. Allocation concealment and generation were graded as adequate, unclear, or inadequate with the criteria suggested in the Cochrane handbook. ${ }^{12} 13$ To assess the effect of study quality on outcomes we performed sensitivity analyses for allocation concealment, allocation generation, and intention to treat versus available case analysis. We performed a modified intention to treat analysis for overall failure in which all drop outs were counted as failure. A funnel plot (1/ standard error plotted against odds ratios) was visually examined to estimate potential selection bias (publication or other). We were able to conduct sensitivity and funnel plot analyses only for the main comparison between tetracycline-aminoglycoside and tetracycline-rifampicin.

We used a $\chi^{2}$ test of heterogeneity and the $\mathrm{I}^{2}$ measure of inconsistency to assess heterogeneity in the results of the trials. ${ }^{12}$ All analyses are shown using the fixed effect model, unless significant heterogeneity $(\mathrm{P}<0.1)$ was present, in which case we used a random effect model. We expected that heterogeneity might originate from different treatment effects among patients with complicated or severe disease. Thus, we performed predefined subgroup analyses for patients with subacute or chronic disease, defined as those presenting after more than two months of symptoms, patients with complicated brucellosis, and patients with brucellosis confirmed by culture.

\section{RESULTS}

The search strategy resulted in 101 potentially relevant publications. We excluded 71 studies (fig 1$)^{\text {w1-w77 }}$ and 
included 30 randomised controlled trials comprising 77 treatment arms. ${ }^{\text {w72-w100 }}$ Table 1 shows details of included studies.

Full characteristics of Brucella infection among included patients and exclusion criteria are in table A on bmj.com. No patients with Brucella endocarditis or neurobrucellosis were included in these trials. The follow-up period ranged from 3 to 36 months. None of the trials reported on mortality as an outcome, nor were specific adverse events reported, except for ototoxicity, and only a few reported on the development of Brucella complications. Six trials reported adequate allocation concealment and 12 reported adequate allocation generation (table 1 and table B on bmj.com). Two trials were double blind, ${ }^{\mathrm{w} 74} \mathrm{w} 97$ and the remaining were open label.

\section{Tetracycline-streptomycin $v$ tetracycline-rifampicin}

Thirteen trials, with 1058 patients, were included in this comparison. ${ }^{\mathrm{w} 72-\mathrm{w} 84}$ Streptomycin was administered for 21 days in eight trial arms and 14-15 days in six, while tetracycline and rifampicin were administered for the duration of treatment, 30-45 days. Overall failure was significantly higher with tetracycline-rifampicin (relative risk 2.30, 95\% confidence interval 1.65 to 3.21 ; fig 2). We found no significant heterogeneity for the overall comparison $\left(\mathrm{P}=0.81, \mathrm{I}^{2}=0 \%\right)$. The difference with regard to overall failure originated mainly from a difference in relapse rates $(2.86,1.84$ to 4.43 ; fig 3$)$.

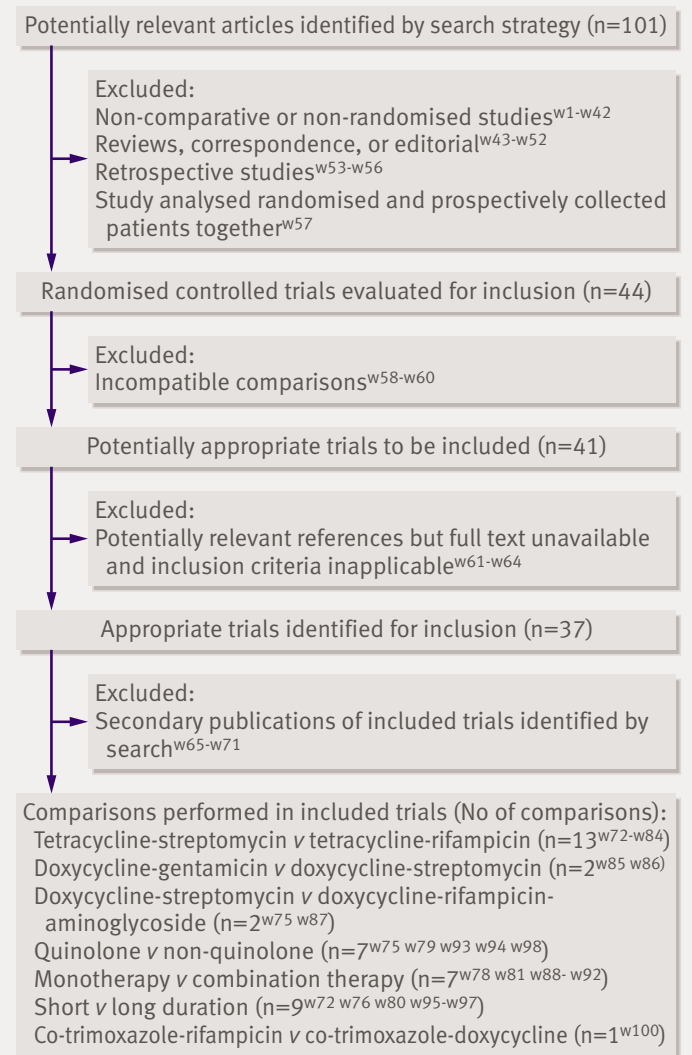

Fig 1 | Flow of studies through trial flow
Therapeutic failure was higher with tetracyclinerifampicin, but the difference was not significant and of smaller magnitude ( $1.54,0.87$ to $2.71 ; 10$ trials). Treatment with tetracycline-rifampicin had to be discontinued more often than treatment with tetracycline-streptomycin (1.43, 1.03 to 2.00). Adverse events in general and discontinuation because of adverse events were similar for the two treatment groups (1.08, 0.84 to 1.39 , and $1.20,0.40$ to 3.59 , respectively; values $>1$ favour the streptomycin arm). Ototoxicity was reported only in the tetracycline-streptomycin group (six of 262 patients, five trials).

Doxycycline was assessed in one of the trial arms of all the trials included in the tetracycline-streptomycin $v$ tetracycline-rifampicin comparison (table 1). When we restricted the analysis to doxycycline-streptomycin versus doxycycline-rifampicin we found a similar trend with a significant disadvantage with doxycyclinerifampicin with regard to overall failure $(2.27,1.62$ to $3.16)$, relapse $(2.80,1.81$ to 4.36$)$, and rates of discontinuation $(1.41,1.01$ to 1.97$)$, without heterogeneity.

Subgroup and sensitivity analyses - Overall failure was higher with tetracycline-rifampicin among patients with brucellosis confirmed by culture $(2.79,1.53$ to 5.08 ; three trials) and among patients with complications of brucellosis (2.63, 1.41 to 4.93 ; four trials). Confidence intervals overlapped for all categories of methodological quality, although quasi-randomised trials tended to exaggerate the advantage of tetracycline-streptomycin (table 2). Exclusion of trials with inadequate concealment of allocation yielded a relative risk of 1.74 (1.14 to 2.65) for overall failure and 2.25 (1.27 to 3.98) for relapse. The funnel plots for overall failure and relapse did not show selection bias.

\section{Quinolone $v$ non-quinolone based regimens}

Five trials compared quinolone-rifampicin with doxycycline-rifampicin. ${ }^{\text {w75 w79 w93 w94 w98 Overall failure was }}$ non-significantly higher in the quinolone group (1.40, 0.77 to 2.52$)$, with no heterogeneity $\left(\mathrm{P}=0.63, \mathrm{I}^{2}=0 \%\right)$. Both relapse $(1.28,0.64$ to 2.53$)$ and therapeutic failure $(1.74,0.59$ to 5.19$)$ were more common in the quinolone arm, but not significantly so. The analysis of adverse events favoured quinolone-rifampicin $(0.37$, 0.22 to 0.63 ; three trials). Discontinuation because of adverse events was reported in a single trial, with no significant difference. ${ }^{\text {w79 }}$

Two trials compared quinolone-rifampicin with doxycycline-streptomycin. ${ }^{\text {w75 w79 }}$ Overall failure was higher in the quinolone arm $(2.28,1.17$ to 4.46$)$, with some heterogeneity $\left(\mathrm{P}=0.13, \mathrm{I}^{2}=57 \%\right)$. Relapse $(3.21$, 1.14 to 9.00$)$ and therapeutic failure $(1.57,0.59$ to 4.16$)$ occurred more often with quinolones. There was no difference in rates of adverse events or discontinuation because of adverse events.

Comparison of any quinolone based regimen versus a regimen without a quinolone showed a significant disadvantage to the quinolone arm with regard to overall failure $(1.83,1.11$ to 3.02 ; fig 4 , with some 


\section{Table 1 |Characteristics of included studies}

\begin{tabular}{|c|c|c|c|c|c|c|c|c|}
\hline Trial & Interventions & $\begin{array}{l}\text { Trial } \\
\text { location }\end{array}$ & Years & Patients & Mean age & Women \% & $\begin{array}{l}\text { Children } \\
\%\end{array}$ & Methods* \\
\hline Acocella $1989^{w 72}$ & $\begin{array}{l}\text { D } 1 \times 200 \mathrm{mg} \text { for } 45 \text { days }+\mathrm{R} 1 \times 900 \mathrm{mg} 1 \text { for } 45 \text { days } v \mathrm{D} 1 \times 200 \mathrm{mg} \text { for } \\
45 \text { days }+\mathrm{S} 1 \times 1 \mathrm{~g} \text { for } 21 \text { days } v \text { TC } 4 \times 0.5 \mathrm{~g} \text { for } 21 \text { days }+\mathrm{S} 1 \times 1 \mathrm{~g} \text { for } \\
14 \text { days }\end{array}$ & $\begin{array}{l}\text { MC: } \\
\text { France, } \\
\text { Greece, } \\
\text { Spain }\end{array}$ & $1981-4$ & 146 & 43 & 41.2 & All >13 & $\mathrm{A}, \mathrm{A}, \mathrm{O}$ \\
\hline Agalar $1999^{\text {w93 }}$ & $\begin{array}{l}\text { D } 2 \times 100 \mathrm{mg} \text { for } 45 \text { days }+\mathrm{R} 1 \times 600 \mathrm{mg} \text { for } 45 \text { days } v \text { CIP } 2 \times 500 \mathrm{mg} \text { for } \\
30 \text { days }+\mathrm{R} 1 \times 600 \mathrm{mg} \text { for } 30 \text { days }\end{array}$ & Turkey & $1995-8$ & 40 & 37.5 (14.9) & 47.5 & & $A, B, 0$ \\
\hline Akova $1993^{\text {w98 }}$ & $\begin{array}{l}\text { D } 1 \times 200 \mathrm{mg} \text { for } 6 \text { weeks }+\mathrm{R} 1 \times 600 \mathrm{mg} \text { for } 6 \text { weeks } v 01 \times 400 \mathrm{mg} \text { for } \\
6 \text { weeks+R } 1 \times 600 \mathrm{mg} \text { for } 6 \text { weeks }\end{array}$ & Turkey & $1989-92$ & 61 & $36.1(14.7)$ & 50.8 & 0 & $\mathrm{~B}, \mathrm{~B}, \mathrm{O}$ \\
\hline Ariza $1985^{\mathrm{w} 88}$ & $\begin{array}{l}\text { C } 2 \times 240-1200 \mathrm{mg} \text { for } 45 \text { days } v \text { TC } 4 \times 0.5 \mathrm{~g} \text { for } 21 \text { days ( } 45 \text { days) } \dagger+ \\
\text { S } 1 \times 1 \mathrm{~g} \text { for } 14 \text { days }\end{array}$ & Spain & $1978-80$ & 58 & $\begin{array}{l}32.5 \\
\text { (range } \\
7-72)\end{array}$ & 18 & All >7 & $\mathrm{B}, \mathrm{B}, \mathrm{O}$ \\
\hline Ariza $1985^{\mathrm{w} 73}$ & $\begin{array}{l}\text { D } 1 \times 100 \mathrm{mg} \text { for } 30 \text { days }(45 \text { days }) \dagger+R 15 \mathrm{mg} / \mathrm{kg} / \text { day for } 30 \text { days } \\
(45 \text { days) } \uparrow v \mathrm{D} 1 \times 100 \mathrm{mg} \text { or TC } 4 \times 0.5 \mathrm{~g} \text { for } 30 \text { days }(45 \text { days }) \dagger+\mathrm{S} 1 \times 1 \mathrm{~g} \\
\text { for } 21 \text { days }\end{array}$ & Spain & $1981-2$ & 56 & $33(14)$ & 20 & All >12 & $\mathrm{C}, \mathrm{C}, \mathrm{O}$ \\
\hline Ariza $1992^{w 74}$ & $\begin{array}{l}\text { D } 2 \times 100 \mathrm{mg} \text { for } 45 \text { days }+\mathrm{R} 15 \mathrm{mg} / \mathrm{kg} / \text { day for } 45 \text { days } v \mathrm{D} 2 \times 100 \mathrm{mg} \text { for } \\
45 \text { days }+\mathrm{S} 1 \times 1 \mathrm{~g} \text { for } 15 \text { days }\end{array}$ & Spain & $1986-9$ & 111 & $26.4(16.3)$ & 28.4 & & $\mathrm{~A}, \mathrm{~A}, \mathrm{DB}$ \\
\hline Bayindir $2003^{w 75}$ & $\begin{array}{l}\text { TC } 4 \times 0.5 \mathrm{~g} \text { for } 45 \text { days }+\mathrm{S} 1 \times 1 \mathrm{~g} \text { for } 15 \text { days } v \mathrm{D} 2 \times 100 \mathrm{mg} \text { for } 45 \text { days } \\
\mathrm{S} 1 \times 1 \mathrm{~g} \text { for } 15 \text { days } v \mathrm{D} 2 \times 100 \mathrm{mg} \text { for } 45 \text { days }+\mathrm{S} 1 \times 1 \mathrm{~g} \text { for } 15 \text { days+ } \\
\mathrm{R} 15 \mathrm{mg} / \mathrm{kg} / \text { day for } 45 \text { days } v \mathrm{D} 2 \times 100 \mathrm{mg} \text { for } 45 \text { days }+\mathrm{R} 15 \mathrm{mg} / \mathrm{kg} / \mathrm{day} \\
\text { for } 45 \mathrm{days} v 02 \times 200 \mathrm{mg} \text { for } 45 \text { days }+\mathrm{R} 15 \mathrm{mg} / \mathrm{kg} / \text { day for } 45 \text { days }\end{array}$ & Turkey & $1992-2001$ & 102 & $\begin{array}{l}40.5 \\
\text { (range } \\
21-69)\end{array}$ & 45 & 0 & $A, A, 0$ \\
\hline Buzon $1982^{\text {w89 }}$ & $\begin{array}{l}\text { TC } 4 \times 0.5 \text { g for } 4 \text { weeks+R } 1200 \mathrm{mg} / \text { day for } 1 \text { week, followed by } 600 \mathrm{mg} / \\
\text { day for } 3 \text { weeks } v \text { C } 480 / 2400 \mathrm{mg} / \text { day for } 10 \text { days and } 320 / 1600 \mathrm{mg} / \\
\text { day for } 20 \text { days, followed by } 160 / 400 \mathrm{mg} / \text { day for } 6 \text { months }\end{array}$ & Spain & NA & $\begin{array}{l}84 \\
\text { patients, } \\
92 \\
\text { episodes }\end{array}$ & - & - & - & $\mathrm{B}, \mathrm{B}, \mathrm{O}$ \\
\hline Colmenero $1989^{\text {w76 }}$ & $\begin{array}{l}\text { D } 2 \times 100 \mathrm{mg} \text { for } 45 \text { days ( } 60 \text { days) } \dagger+R 15 \mathrm{mg} / \mathrm{kg} / \text { day for } 45 \text { days } \\
\text { ( } 60 \text { days) } \uparrow v \mathrm{D} 2 \times 100 \mathrm{mg} \text { for } 30 \text { days }(60 \text { days }) \dagger+S 1 \times 1 \mathrm{~g} \text { for } 21 \text { days }\end{array}$ & Spain & $1985-6$ & 111 & $33.1(3.7)$ & 30.6 & - & $\mathrm{B}, \mathrm{B}, \mathrm{O}$ \\
\hline Colmenero $1994^{\mathrm{w} 77}$ & $\begin{array}{l}\text { D } 2 \times 100 \mathrm{mg} \text { for } 6 \text { weeks }(12 \text { weeks }) \dagger+R 10-15 \mathrm{mg} / \mathrm{kg} / \text { day for } 6 \text { weeks } \\
(12 \text { weeks) } \uparrow v \mathrm{D} 2 \times 100 \mathrm{mg} \text { for } 6 \text { weeks }(12 \text { weeks) } \dagger+\mathrm{S} 1 \times 1 \mathrm{~g} \text { for } 3 \text { weeks }\end{array}$ & Spain & NA & 19 & $33.3(15.6)$ & 35 & - & $\mathrm{B}, \mathrm{B}, \mathrm{O}$ \\
\hline Dorado $1988^{\text {w78 }}$ & $\begin{array}{l}\text { D } 1 \times 200 \mathrm{mg} \text { for } 28 \text { days+R } 1 \times 1200 \mathrm{mg} \text { for } 7 \text { days, followed by } \\
1 \times 600 \mathrm{mg} \text { for } 21 \text { days } V \text { D } 1 \times 200 \mathrm{mg} \text { for } 40 \text { days }+S 1 \times 1 \mathrm{~g} \text { for } 21 \text { days } v \\
\text { C } 480 / 2400 \mathrm{mg} / \text { day for } 7 \text { days, followed by C } 320 / 1600 \mathrm{mg} / \text { day for } \\
21 \text { days, followed by } 160 / 800 \mathrm{mg} / \text { day for } 60 \text { days }\end{array}$ & - & $1983-7$ & 73 & 37.2 & 63 & - & $\mathrm{B}, \mathrm{B}, \mathrm{O}$ \\
\hline Ersoy $2005^{\text {w79 }}$ & $\begin{array}{l}0400 \mathrm{mg} / \text { day for } 6 \text { weeks+R } 600 \mathrm{mg} / \text { day for } 6 \text { weeks } v \mathrm{D} 200 \mathrm{mg} / \text { day } \\
\text { for } 6 \text { weeks+R } 600 \mathrm{mg} / \text { day for } 6 \text { weeks } v \text { D } 100 \mathrm{mg} / \text { day for } 6 \text { weeks+ } \\
\mathrm{S} 1 \mathrm{~g} / \text { day for } 3 \text { weeks }\end{array}$ & Turkey & 1997- 2002 & 129 & $36.4(2.2)$ & 47.4 & 0 & $\mathrm{~B}, \mathrm{~B}, \mathrm{O}$ \\
\hline Espinosa $1997^{\text {w85 }}$ & $\begin{array}{l}\text { D } 2 \times 100 \mathrm{mg} \text { for } 30-45 \text { days ( } 90 \text { days) }++\mathrm{G} 240 \mathrm{mg} / \text { day for } 7 \text { days } v \\
\text { D } 2 \times 100 \mathrm{mg} \text { for } 30-45 \text { days }(90 \text { days) } \dagger+S 1 \times 1 \mathrm{~g} \text { for } 14 \text { days }\end{array}$ & Spain & NA & 40 & $\begin{array}{l}31.5 \\
\text { (range } \\
8-74)\end{array}$ & & - & $\mathrm{B}, \mathrm{B}, \mathrm{O}$ \\
\hline Feiz $1973^{\text {w90 }}$ & $\begin{array}{l}\mathrm{D} 4 \mathrm{mg} / \mathrm{kg} / \text { day for } 14 \text { days, followed by } 2 \mathrm{mg} / \mathrm{kg} / \text { day for } 7 \text { days } v \text { TO up } \\
\text { to } 2 \mathrm{~g} / \text { day for } 21 \text { days+S up to } 1 \mathrm{~g} / \text { day for } 14 \text { days } v \text { TO up to } 2 \mathrm{~g} / \text { day for } \\
21 \text { days }\end{array}$ & Iran & 1971 & 95 & Range 1-50 & 51 & - & $\mathrm{C}, \mathrm{C}, \mathrm{O}$ \\
\hline Kalo $1996^{\text {w99 }}$ & $\begin{array}{l}\text { D } 200 \mathrm{mg} / \text { day for } 6 \text { weeks+R } 900 \mathrm{mg} / \text { day for } 6 \text { weeks } v \text { D } 200 \mathrm{mg} / \text { day } \\
\text { for } 6 \text { weeks+CIP } 1 \mathrm{~g} / \text { day for } 6 \text { weeks }\end{array}$ & Albania & $1992-4$ & 24 & $31.8(13.5)$ & 42 & 0 & $\mathrm{C}, \mathrm{C}, \mathrm{O}$ \\
\hline Karabay $2004^{\text {w94 }}$ & $\begin{array}{l}\text { D } 1 \times 200 \mathrm{mg} \text { for } 45 \text { days }+\mathrm{R} 1 \times 600 \mathrm{mg} \text { for } 45 \text { days } v 01 \times 400 \mathrm{mg} \text { for } \\
30 \text { days }+\mathrm{R} 1 \times 600 \mathrm{mg} \text { for } 30 \text { days }\end{array}$ & Turkey & $1999-2001$ & 34 & $\begin{array}{l}\text { Median } 32 \\
\text { (range 18- } \\
\quad 61 \text { ) }\end{array}$ & 17 & 0 & $\mathrm{~A}, \mathrm{~A}, \mathrm{O}$ \\
\hline Kosmidis $1982^{\text {w80 }}$ & $\begin{array}{l}\text { D } 1 \times 200 \mathrm{mg} \text { for } 45 \text { days }+\mathrm{R} 1 \times 900 \mathrm{mg} \text { for } 45 \text { days } v \mathrm{D} 1 \times 200 \mathrm{mg} \text { for } \\
45 \text { days }+\mathrm{S} 1 \times 1 \mathrm{~g} \text { for } 21 \text { days } v \text { TC } 4 \times 0.5 \mathrm{~g} \text { for } 21 \text { days }+\mathrm{S} 1 \times 1 \mathrm{~g} \text { for } \\
14 \text { days }\end{array}$ & Greece & NA & 29 & - & - & - & $\mathrm{B}, \mathrm{B}, \mathrm{O}$ \\
\hline Lang $1990^{\text {w92 }}$ & $\begin{array}{l}\text { D } 2 \times 100 \mathrm{mg} \text { for } 6 \text { weeks }+\mathrm{R} 2 \times 300 \mathrm{mg} \text { for } 6 \text { weeks } v \text { CIP } 2 \times 1 \mathrm{~g} \text { for } \\
6 \text { weeks } v \text { CIP } 2 \times 750 \mathrm{mg} \text { for } 6 \text { weeks }\end{array}$ & Israel & NA & 11 & $37.4(12.6)$ & 43.7 & 0 & $A, B, 0$ \\
\hline Lang $1992^{\text {w91 }}$ & $\begin{array}{l}\text { CEF up to } 75 \mathrm{mg} / \mathrm{kg} / \text { day for at least } 14 \text { days } v \mathrm{D} 1 \times 100 \mathrm{mg} \text { for } 28 \text { days+ } \\
\mathrm{S} 20 \mathrm{mg} / \mathrm{kg} / \text { day for } 14 \text { days }\end{array}$ & Israel & 1989 & 18 & $28.4(13.5)$ & 72 & 22 & $\mathrm{~B}, \mathrm{~B}, \mathrm{O}$ \\
\hline Lubani $1989^{\text {w95 }}$ & $\begin{array}{l}\text { Any treatment for } 3 \text { weeks } v \text { any treatment for } 5 \text { weeks } v \text { any treatment } \\
\text { for } 8 \text { weeks }\end{array}$ & Kuwait & $1981-6$ & 1100 & $\begin{array}{l}6.8 \text { (range } \\
0-14 \text { ) }\end{array}$ & 43 & 100 & $\mathrm{~B}, \mathrm{~B}, \mathrm{O}$ \\
\hline Montejo 1993aw81 & $\begin{array}{l}\text { D } 1 \times 200 \mathrm{mg} \text { for } 28 \text { days }+\mathrm{R} 1 \times 1200 \mathrm{mg} \text { for } 7 \text { days, followed by } \\
\text { R } 1 \times 600 \mathrm{mg} \text { for } 21 \text { days } v \text { C } 3 \times 160 / 800 \mathrm{mg} \text { for } 10 \text { days, followed by } \\
\text { C } 2 \times 160 / 800 \mathrm{mg} \text { for } 18 \text { days, followed by } C 2 \times 80 / 400 \mathrm{mg} \text { for } 5 \text { months } v \\
\text { D } 1 \times 200 \mathrm{mg} \text { for } 6 \text { weeks }\end{array}$ & Spain & $1980-3$ & 200 & $\begin{array}{l}46 \text { (range } \\
14-82)\end{array}$ & 27 & - & $\mathrm{A}, \mathrm{A}, \mathrm{O}$ \\
\hline Montejo $1993 b^{w 81}$ & $\begin{array}{l}\text { D } 1 \times 200 \mathrm{mg} \text { for } 6 \text { weeks }+\mathrm{S} 1 \times 1 \mathrm{~g} \text { for } 3 \text { weeks } v \text { D } 1 \times 200 \mathrm{mg} \text { for } 6 \text { weeks } \\
+\mathrm{R} 1 \times 900 \mathrm{mg} \text { for } 6 \text { weeks } v \text { D } 2001 \times \mathrm{mg} \text { for } 6 \text { weeks }+\mathrm{S} 1 \times 1 \mathrm{~g} \text { for } 2 \text { weeks }\end{array}$ & Spain & $1984-7$ & 130 & $\begin{array}{l}46 \text { (range } \\
14-82)\end{array}$ & 26 & All >14 & $\mathrm{A}, \mathrm{A}, \mathrm{O}$ \\
\hline Ranjbar $2007^{\mathrm{w} 87}$ & $\begin{array}{l}\text { D } 2 \times 100 \mathrm{mg} \text { for } 8 \text { weeks+R } 10 \mathrm{mg} / \mathrm{kg} / \text { day for } 8 \text { weeks } v \mathrm{D} 2 \times 100 \mathrm{mg} \text { for } \\
8 \text { weeks+R } 10 \mathrm{mg} / \mathrm{kg} / \text { day for } 8 \text { weeks }+\mathrm{G} 2 \times 7.5 \mathrm{mg} / \mathrm{kg} \text { for } 7 \text { days }\end{array}$ & Iran & $1999-2001$ & 228 & $36.4(17.7)$ & 51.3 & All $>8$ & $A, B, O$ \\
\hline $\begin{array}{l}\text { Rodriguez Zap. } \\
1987^{\text {w82 }}\end{array}$ & $\begin{array}{l}\text { D } 1 \times 200 \mathrm{mg} \text { for } 45 \text { days }+\mathrm{R} 1 \times 900 \mathrm{mg} \text { for } 45 \text { days } v \mathrm{D} 2 \times 200 \mathrm{mg} \text { for } \\
21 \text { days }+\mathrm{S} 1 \times 1 \mathrm{~g} \text { for } 21 \text { days }\end{array}$ & Spain & NA & 72 & $\begin{array}{l}36 \text { (range } \\
14-65)\end{array}$ & 20 & All >13 & $\mathrm{B}, \mathrm{B}, \mathrm{O}$ \\
\hline
\end{tabular}




\begin{tabular}{|c|c|c|c|c|c|c|c|c|}
\hline Trial & Interventions & $\begin{array}{l}\text { Trial } \\
\text { location }\end{array}$ & Years & Patients & Mean age & Women \% & $\begin{array}{l}\text { Children } \\
\%\end{array}$ & Methods* \\
\hline Roushan $2004^{\mathrm{w} 100}$ & $\begin{array}{l}\text { C } 8 \mathrm{mg} / \mathrm{kg} / \text { day trimethoprim for } 60 \text { days }+D 2 \times 100 \mathrm{mg} \text { for } 60 \text { days } v \\
\text { C } 8 \mathrm{mg} / \mathrm{kg} / \text { day trimethoprim for } 60 \text { days }+\mathrm{R} 15 \mathrm{mg} / \mathrm{kg} / \text { day for } 60 \text { days }\end{array}$ & Iran & 1999-2002 & 280 & $33.5(17)$ & 46.4 & All >10 & $A, B, 0$ \\
\hline Roushan $2005^{\text {w96 }}$ & $C+R$ for 6 weeks $v C+R$ for 8 weeks (doses not available) & Iran & $1998-2003$ & 79 & $9.3(3.2)$ & 48 & 100 & $\mathrm{~B}, \mathrm{~B}, \mathrm{O}$ \\
\hline Roushan $2006^{\text {w86 }}$ & $\begin{array}{l}\text { D } 2 \times 100 \mathrm{mg} \text { for } 45 \text { days }+\mathrm{S} 1 \times 1 \mathrm{~g} \text { for } 14 \text { days } v \mathrm{D} 2 \times 100 \mathrm{mg} \text { for } 45 \text { days } \\
+\mathrm{G} 5 \mathrm{mg} / \mathrm{kg} / \text { day for } 7 \text { days }\end{array}$ & Iran & 2003-5 & 200 & $35(15.4)$ & 43 & All >15 & $A, B, 0$ \\
\hline Solera $1991^{\text {w83 }}$ & $\begin{array}{l}\text { D } 2 \times 100 \mathrm{mg} \text { for } 45 \text { days+R } 1 \times 900 \mathrm{mg} \text { for } 21 \text { days } v \mathrm{D} 2 \times 100 \mathrm{mg} \text { for } \\
45 \text { days }+\mathrm{S} 1 \times 1 \mathrm{~g} \text { for } 14 \text { days }\end{array}$ & MC Spain & $1987-9$ & 84 & $32(16)$ & 23 & All $>7$ & $\mathrm{C}, \mathrm{C}, \mathrm{O}$ \\
\hline Solera $1995^{\text {w84 }}$ & $\begin{array}{l}\text { D } 2 \times 100 \mathrm{mg} \text { for } 45 \text { days }+\mathrm{R} 1 \times 900 \mathrm{mg} \text { for } 45 \text { days } v \mathrm{D} 2 \times 100 \mathrm{mg} \text { for } \\
45 \text { days }+\mathrm{S} 1 \times 1 \mathrm{~g} \text { for } 14 \text { days }\end{array}$ & MC Spain & $\begin{array}{c}1989-93 \\
1987-9\end{array}$ & 194 & $\begin{array}{c}33.5 \\
\text { (range } 7- \\
77)\end{array}$ & 18 & All >7 & $\mathrm{C}, \mathrm{C}, \mathrm{O}$ \\
\hline Solera $2004^{\text {w97 }}$ & $\begin{array}{l}\text { D } 2 \times 100 \mathrm{mg} \text { for } 30 \text { days }+\mathrm{G} 1 \times 240 \mathrm{mg} \text { for } 7 \text { days } v \mathrm{D} 2 \times 100 \mathrm{mg} \text { for } \\
45 \text { days }+\mathrm{G} 1 \times 240 \mathrm{mg} \text { for } 7 \text { days }\end{array}$ & MC Spain & $1995-9$ & 167 & $38.9(14.6)$ & 16.4 & 0 & $\mathrm{~A}, \mathrm{~A}, \mathrm{DB}$ \\
\hline
\end{tabular}

$M C=$ multicentre; $D=$ doxycycline, $R=$ rifampicin, $S=$ streptomycin, $T C=$ tetracycline hydrochloride, $T O=$ oxytetracycline, $C \mid P=$ ciprofloxacin, $O=0$ ofloxacin, $C=$ co-trimoxazole $($ dosing refers to

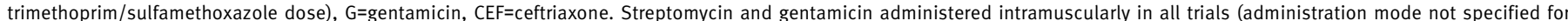

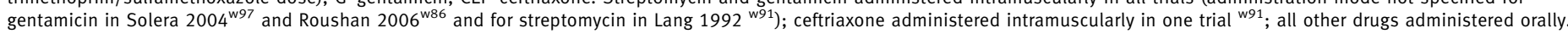
NA=not available.

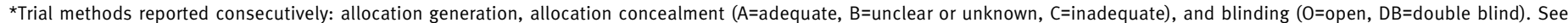
table B on bmj.com for details of methods used in trials.

†Duration of treatment among patients with complications of brucellosis (such as spondylitis) given in parentheses.

heterogeneity $\left(\mathrm{P}=0.14, \mathrm{I}^{2}=42.9 \%\right)$. Subgroup analyses were scarce. Overall failure was significantly higher with quinolone based regimens among patients with complicated brucellosis in two trials, without heterogeneity $(2.93,1.48$ to 5.78$)$.

\section{Monotherapy $v$ combination treatment regimens}

Seven trials assessed monotherapy. ${ }^{\text {w78 w81 w88-w92 }}$ The studies were subcategorised according to the type of monotherapy. When co-trimoxazole was the monotherapy, overall failure was not significantly different (1.27, 0.81 to 1.99 ; three trials, 257 patients), though therapeutic failure was more common $(2.49,1.26$ to 4.89; three trials, 294 patients). For tetracycline monotherapy (two trials, 211 patients), the respective relative risks were 1.01 (0.58 to 1.77$)$ and $0.25(0.03$ to 2.32). Two small trials that assessed ceftriaxone and

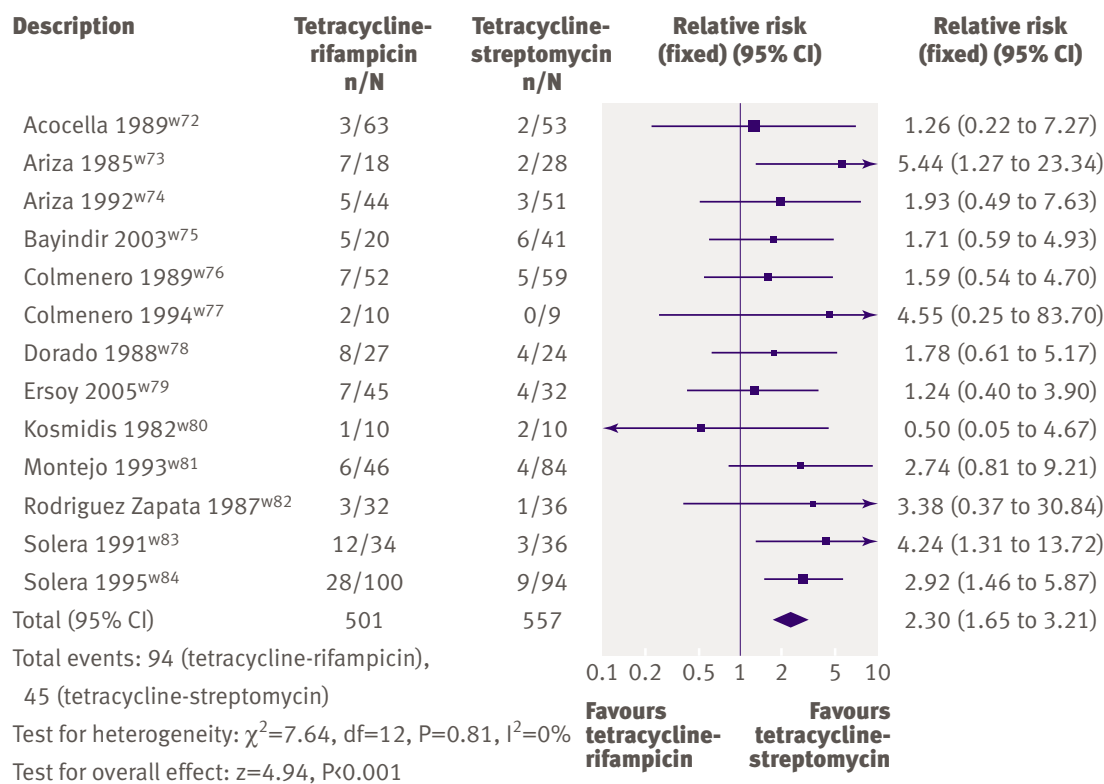

Fig 2 | Overall failure (defined as failure of assigned regimen or relapse) with tetracycline-rifampicin $v$ tetracycline-streptomycin ciprofloxacin as monotherapy were stopped early because of a significant disadvantage in the monotherapy arm. ${ }^{\mathrm{w} 91 \mathrm{w} 92}$ Two trials assessed six months of cotrimoxazole monotherapy compared with short term combination therapy (28 days). ${ }^{\text {w81 w89 }}$ When we limited the analysis to trials that compared similar durations of treatment for combination treatment and monotherapy, overall failure was more common with monotherapy (2.56, 1.55 to 4.23 ; five trials), while the two trials that compared long monotherapy with short combination therapy found no significant difference. No heterogeneity was observed with all these comparisons, but the overall level of heterogeneity meant we could not carry out a combined assessment of all monotherapy versus combination therapy.

\section{Short ( $<30$ days’) $v$ long ( $\geq 6$ weeks’) duration of treatment}

Four trials compared duration of treatment with the same or similar regimens in both trial arms (see table 1). w72 w80 w95 w97 Overall failure was significantly more common with short treatment duration (3.08, 1.01 to 9.38 ; random effects model $\mathrm{P}=0.07$ and $\mathrm{I}^{2}=61.9 \%$ for heterogeneity). Both therapeutic failure (3.02, 1.03 to 8.80$)$ and relapse $(1.70,1.19$ to 2.44$)$ were significantly more common with the shorter duration, without significant heterogeneity.

Four trials examined short duration (21-30 days) doxycycline-streptomycin compared with long duration doxycycline-rifampicin. ${ }^{\text {w72 w76 w80 w82 Relapse rates }}$ were non-significantly higher with short duration doxycycline-streptomycin $(2.29,0.87$ to 6.03$)$ with no significant heterogeneity. The differences in overall failure and therapeutic failure were not significant, and both comparisons were significantly heterogeneous (1.74, 0.35 to 8.72 , and $4.02,0.35$ to 46.42 , respectively, random effects model).

Among all trials assessing short compared with long durations of treatment, rates of adverse events did not differ significantly between the study groups. 


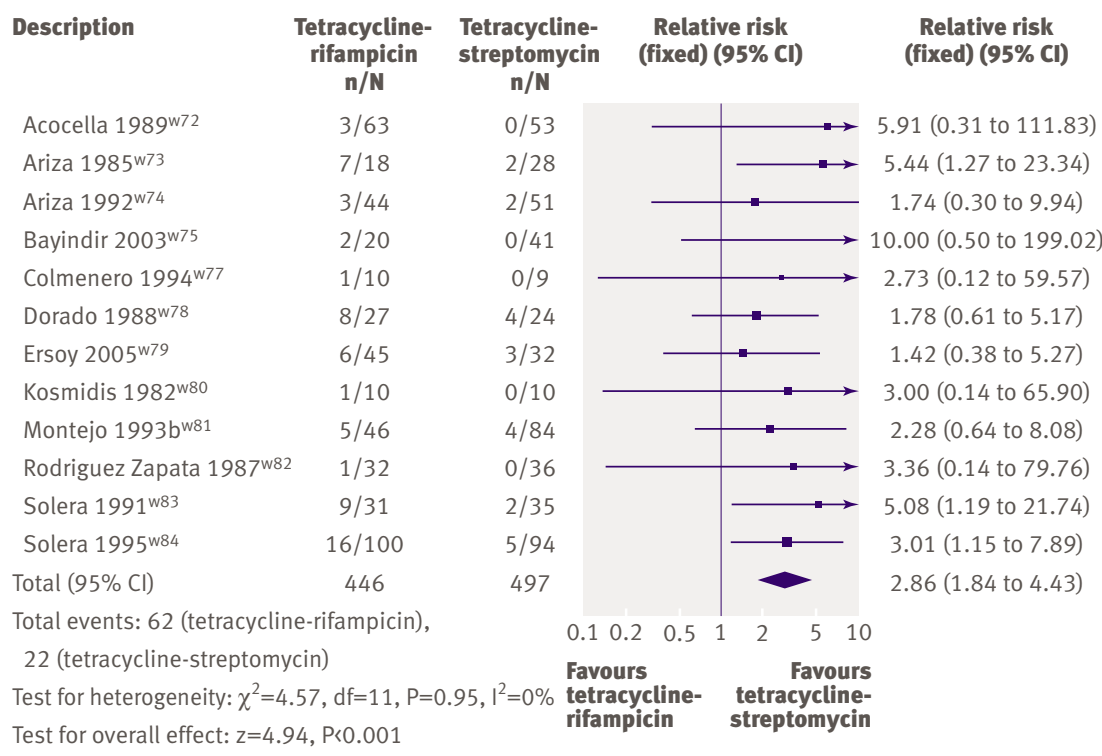

Fig 3 | Relapse with tetracycline-rifampicin $v$ tetracycline-streptomycin

\section{Other comparisons}

Streptomycin v gentamicin - Two trials compared streptomycin with gentamicin, both in combination with a tetracycline. ${ }^{\text {w85 w86 }}$ Rates of failure and relapse were higher with streptomycin, but the results were not significant $(1.45,0.52$ to 4.00 , for overall failure; 2.50 , 0.56 to 11 , for therapeutic failure; $1.19,0.33$ to 4.35 , for relapse). Adverse events were similar overall, while adverse events leading to discontinuation were less common with gentamicin $(0.19,0.01$ to 3.99$)$. No heterogeneity was observed in these comparisons.

Dual $\mathrm{v}$ triple drug regimens - Two trials compared doxycycline-streptomycin with doxycycline-rifampicin-aminoglycoside. ${ }^{\text {w75 w87 }}$ Overall failure was significantly higher with the dual drug regimen $(2.50,1.26$ to 5.00 , without heterogeneity). Rates of therapeutic failure $(3.85,1.37$ to 11.0$)$ and relapse $(1.49,0.55$ to 4.0) were also in higher with the dual regimen, although the confidence intervals are wide. No adverse events that required discontinuation of treatment occurred in both trials.
Doxycycline v tetracycline - Four trials compared doxycycline with tetracycline. There were no differences between these drugs when administered for a similar duration of time (two trials). ${ }^{\text {w75 }}{ }^{\text {w90 }}$ A shorter regimen of doxycycline-streptomycin was significantly inferior to a longer regimen of tetracycline-streptomycin (two trials, $6.25,2.44$ to 16.7 , for overall failure). ${ }^{\text {772 w80 }}$

Other-Two trials were not included in previous comparisons. One trial assessed the combination of cotrimoxazole-rifampicin compared with co-trimoxazole-doxycycline. ${ }^{\text {w100 }}$ Overall failure and treatment failure were significantly more common without doxycycline $(1.79,1.08$ to 2.98 , and $2.86,1.25$ to 6.54 , respectively). One small trial compared six with eight weeks of cotrimoxazole-rifampicin. ${ }^{\text {w96 }}$ Overall failure was non-significantly higher with the shorter treatment $(5.56,0.70$ to 44.09$)$.

\section{DISCUSSION}

In this systematic review on the treatment of brucellosis we compared the specific drugs used in treatment regimens, monotherapy, dual and triple drug regimens, and duration of treatment in 30 randomised controlled trials.

The combination of tetracycline-streptomycin was significantly superior to tetracycline-rifampicin, mainly with regard to rates of relapse. The relative risk for relapse with tetracycline-rifampicin was 2.86 (1.84 to 4.43$)$, translating into a number needed to treat of 11 (8 to 17) with tetracycline-streptomycin to prevent one relapse after treatment with tetracycline-rifampicin. The tetracycline administered to 1038 out of 1058 patients included in this comparison was doxycycline, thus these results apply mainly to the comparison of doxycycline-streptomycin $v$ doxycycline-rifampicin. Adverse events were no more common with the aminoglycoside based regimen. When streptomycin was compared with gentamicin we observed a trend in favour of gentamicin for all outcomes, though results were not statistically significant because of the small sample size. Thus, gentamicin could replace streptomycin in combination regimens for brucellosis. Quinolones were assessed in combination with rifampicin

Table 2 | Effect of assessment of methodological quality on primary outcomes in trials comparing tetracycline-streptomycin with tetracycline-rifampicin. Figures are relative risks ( $95 \%$ confidence intervals)

\begin{tabular}{|c|c|c|c|}
\hline & Adequate & Unclear/unknown & Inadequate \\
\hline \multicolumn{4}{|l|}{ Overall failure } \\
\hline Allocation generation & $1.93(1.02$ to 3.66$), 4$ trials & 1.60 (0.91 to 2.82$), 6$ trials & $3.49(2.01$ to 6.05$), 3$ trials \\
\hline Allocation concealment & 2.08 (1.04 to 4.14$), 3$ trials & 1.56 (0.92 to 2.67$), 7$ trials & 3.49 (2.01 to 6.05$), 3$ trials \\
\hline Intention to treat* & 2.24 (1.38 to 3.63), 5 trials & 1.65 (0.90 to 3.04$), 4$ trials & 3.59 (1.77 to 7.28$), 4$ trials \\
\hline Modified intention to treat $\dagger$ & 2.27 (1.66 to 3.10), 9 trials & 1.65 (0.90 to 3.04$), 4$ trials & - \\
\hline \multicolumn{4}{|l|}{ Relapse } \\
\hline Allocation generation & 2.92 (1.19 to 7.15$), 4$ trials & 1.84 (0.87 to 3.90$), 5$ trials & 3.90 (1.94 to 7.84$), 3$ trials \\
\hline Allocation concealment & 2.59 (1.02 to 6.62$), 3$ trials & 2.07 (1.01 to 4.26 ), 6 trials & 3.90 (1.94 to 7.84$), 3$ trials \\
\hline Intention to treat & 2.73 (1.42 to 5.24$), 5$ trials & 2.13 (0.90 to 5.03 ), 3 trials & 3.79 (1.72 to 9.13$), 4$ trials \\
\hline
\end{tabular}

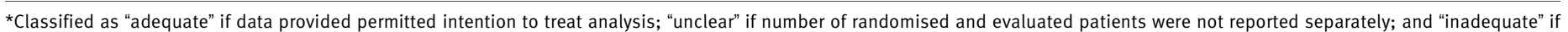
only efficacy analysis was provided.

†Modified intention to treat: all drop outs counted as treatment failure. 
Table 3 | Recommendations for the treatment of uncomplicated brucellosis among non-pregnant adults

\begin{tabular}{|c|c|c|c|}
\hline & WHO/FAO 19864 & Ioannina 20079 & Current review* \\
\hline First line regimen & Doxycycline 6 weeks+rifampicin 6 weeks & Doxycycline 6 weeks+streptomycin $2-3$ weeks & $\begin{array}{l}\text { Doxycycline } 6 \text { weeks+rifampicin } 6 \text { weeks+gentamicin } \\
2 \text { weeks OR doxycycline } 6 \text { weeks+gentamicin } 2 \text { weeks }\end{array}$ \\
\hline Alternative & Tetracycline 6 weeks+streptomycin 2-3 weeks & Doxycycline 6 weeks+rifampicin 6 weeks & Doxycycline 6 weeks+streptomycin 2 weeks \\
\hline Second line regimen & - & Doxycycline 6 weeks+gentamicin 1 week & $\begin{array}{l}\text { Doxycycline+rifampicin } 6 \text { weeks OR tetracycline } 6 \text { weeks } \\
\text { +gentamicin/streptomycin } 2 \text { weeks }\end{array}$ \\
\hline Optional, poor evidence & Co-trimoxazole & $\begin{array}{l}\text { Co-trimoxazole+doxycycline+other } 6 \text { weeks OR } \\
\text { ofloxacin or ciprofloxacin+doxycycline+/-other } \\
6 \text { weeks }\end{array}$ & Co-trimoxazole+doxycycline/rifampicin 6 weeks \\
\hline Not recommended & - & Azithromycin OR meropenem & $\begin{array}{l}\text { Monotherapy OR }<30 \text { days of treatment OR quinolone } \\
\text { with or without rifampicin/doxycycline }\end{array}$ \\
\hline
\end{tabular}

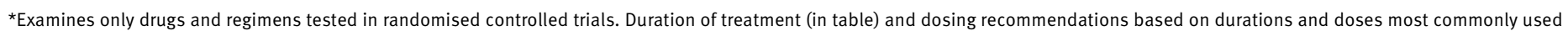

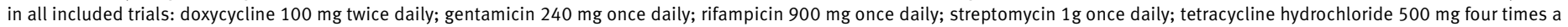
day. Aminoglycosides administered intramuscularly and other drugs orally.

and were less effective than doxycycline with rifampicin or streptomycin. Although the adverse events profile may favour quinolone-rifampicin, this regimen cannot be recommended because of its lower effectiveness. Quinolone-aminoglycoside regimens were not assessed.

Trials assessing monotherapy looked at tetracycline, co-trimoxazole, ciprofloxacin, or ceftriaxone monotherapy compared with combination therapy. When these drugs were administered for similar durations, the risk for overall failure with monotherapy was more than twice (relative risk 2.56) that of combination therapy. Data on long term co-trimoxazole monotherapy were too limited to assess. Two trials assessed triple combination therapy with tetracycline-aminoglycoside-rifampicin and found it to be significantly more effective than the most effective dual regimen of tetracycline-aminoglycoside. The main difference was in primary failure of the regimen with an NNT of 10 patients (6 to 33) with triple combination therapy to prevent one therapeutic failure with dual therapy.

Finally, treatment duration of six weeks or more resulted in a lower frequency of relapse than three to four weeks' treatment. The main outcome to consider in this comparison is the relapse rate. Both long duration tetracycline-aminoglycoside and tetracycline-rifampicin were more effective than short duration tetracycline-aminoglycoside therapy, with NNTs of 20 (12 to 50$)$ and 9 (5 to 100) patients, respectively, to prevent one relapse.

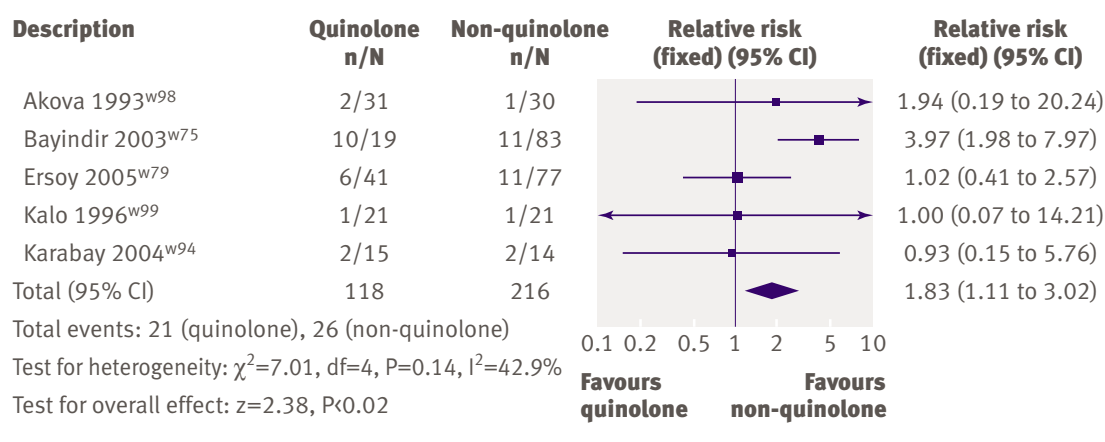

Fig 4 | Overall failure (defined as failure of assigned regimen or relapse) for treatment with or without quinolone
We conducted a comprehensive search, but we could have missed trials from Latin-America or the Middle East published in languages other than English. Furthermore, we could not obtain the full text for four potentially eligible trials, ${ }^{\text {w61-w64 }}$ despite attempts to contact corresponding authors, other researchers, and Cochrane review groups. We included five pseudorandomised trials (using odd or even patients' age, order of appearance in the clinic, or a sequential design for randomisation) in our meta-analysis. ${ }^{\text {w73 w83 w84 w90 w99 }}$ We observed an exaggeration of the treatment effects with these trials, although their exclusion from analysis did not alter the results or their significance. Finally, none of the included trails had participants with endocarditis or neurobrucellosis, thus our results do not apply to such patients.

\section{Recommendations}

Table 3 summarises the recommendations from our systematic review compared with previous recommendations. According to results of two trials, the optimal treatment regimen for brucellosis is doxycyclineaminoglycoside-rifampicin, with the aminoglycoside administered for the first seven to 14 days and doxycycline-rifampicin continued for six to eight weeks. Tetracycline-streptomycin is significantly more effective than tetracycline-rifampicin. Gentamicin was not inferior to streptomycin. Tetracycline could replace doxycycline if local costs need to be considered, although the bulk of evidence is based on treatment with doxycycline. Treatment should be administered for six weeks or longer as treatment for 30 days or less results in an increased relapse rate, even with the more potent doxycycline-streptomycin regimen. Quinolones cannot currently be recommended, either as monotherapy or in combination therapy, as the available evidence shows them to be less effective than the traditional regimens. Formal guidelines should be updated following the evidence accrued to date.

Children aged under 8 and pregnant women cannot be treated with tetracyclines and quinolones. WHO guidelines recommend rifampicin monotherapy, while other sources recommend co-trimoxazole monotherapy ${ }^{14}$ or the combination of these two anti 


\section{WHAT IS ALREADY KNOWN ON THIS TOPIC}

Several classic combination regimens are available for the treatment of brucellosis in addition to newer antibiotics, such as quinolones

Many randomised controlled trials have assessed these regimens, though the evidence has not recently been summarised

Treatment recommendations from authoritative sources are contradictory

\section{WHAT THIS STUDY ADDS}

A triple drug regimen of doxycycline, gentamicin, and rifampicin offers an advantage over doxycycline with an aminoglycoside, and doxycycline-aminoglycoside regimens are superior to doxycycline-rifampicin

Quinolones are inferior to other drugs

Six weeks' treatment is associated with a lower rate of relapse than shorter regimens

biotics. ${ }^{15}$ Though data are limited, our results support the use of co-trimoxazole monotherapy for a prolonged period of time (up to six months).

Further trials are needed to establish the superiority and safety of the triple drug regimens. Further comparisons of doxycycline-aminoglysoside and doxycycline-rifampicin regimens are no longer needed. Trials of quinolones are justified only in triple drug regimens, if newer quinolones with more potent activity against Brucella are developed, and perhaps in combination with aminoglycosides. The assessment of patients with specific complications of brucellosis is difficult in randomised controlled trials because of the rarity of the disease and its complicated form. An effort should be made to include them in multi-centre trials, and these patients should be assessed in prospective long term observational studies.

We thank M Akova, Y Bayindir, and O Karabay for supplying additional data on their trials. Data for Dorado Pombo et al ${ }^{w 78}$ were obtained from a previously published meta-analysis by Solera et al. ${ }^{10}$

Contributors: DY, MP, and LL were responsible for conception and design $\mathrm{KS}$, DY, and MP searched for and retrieved articles and extracted and analysed data. KS, DY, LL, and MP were responsible for interpretation and writing. IB and SP critically revised the manuscript, which was approved by all authors. MP is guarantor.

Funding: None.

Competing interests: None declared

Ethics approval: Not required.

Provenance and peer review: Not commissioned; externally peer reviewed.

1 Pappas G, Papadimitriou P, Akritidis N, Christou L, Tsianos EV. The new global map of human brucellosis. Lancet Infect Dis 2006;6:91-9.

2 Pappas G, Akritidis N, Bosilkovski M, Tsianos E. Brucellosis. N Engl J Med 2005;352:2325-36.

3 Spink KW. Current status of therapy of brucellosis in human beings. JAMA 1960;172:697-8.

4 Joint WHO/FAO expert committee on brucellosis. 6th report. WHO Tech Rep Ser 1986;740:1-132.

5 Corbel MJ, Beeching NJ. Brucellosis. In: Kasper DL, Braunwald E, Hauser S, Longo D, Jameson JL, Fauci AS, eds. Harrison's principles of internal medicine. 16th ed. USA: McGraw-Hill, 2005.

6 Young EJ. Brucella Species. In: Mandell GL, Bennett JE, Dolin R, eds. Principles and practice of infectious diseases. 6th ed. Philadelphia: Elsevier Churchill Livingstone, 2005.

7 Everett ED. Clinical manifestations, diagnosis, and treatment of brucellosis in adults. UpToDate, 2007. http://patients.uptodate. com/topic.asp?file=gram_rod/7017.

8 Franco MP, Mulder M, Gilman RH, Smits HL. Human brucellosis. Lancet Infect Dis 2007;7:775-86.

9 Ariza J, Bosilkovski M, Cascio A, Colmenero JD, Corbel MJ, Falagas ME, et al. Perspectives for the treatment of brucellosis in the 21st century: the loannina recommendations. PLoS Med 2007;4:e317.

10 Solera J, Martinez-Alfaro E, Saez L. [Meta-analysis of the efficacy of the combination of +rifampicin and doxycycline in the treatment of human brucellosis]. Med Clin (Barc) 1994;102:731-8.

11 In: Alderson P, Green S, Higgins JPT, eds. Highly sensitive search strategies for identifying reports of randomized controlled trials in Medline. In: Higgins JPT, Green S, eds. Cochrane handbook for systematic reviews of interventions 4.2.5. Chichester: John Wiley, 2005 (appendix 5b, issue 3, updated May 2005).

12 In: Higgins JPT, Green S, eds. Cochrane handbook for systematic reviews of interventions 4.2.5. Chichester: John Wiley, 2005 (issue 3, updated May 2005).

13 Moher D, Pham B, Jones A, Cook DJ, Jadad AR, Moher M, et al. Does quality of reports of randomised trials affect estimates of intervention efficacy reported in meta-analyses? Lancet 1998;352:609-13.

14 Salata RA. Brucellosis. In: Goldman L, ed. Cecil textbook of medicine. 22nd ed. Philadelphia, Pennsylvania: WB Saunders, 2004.

15 Everett ED. Brucellosis in children. UpToDate, 2007. http://patients. uptodate.com/topic.asp?file=pedi_id/7228\&title=Brucellosis.

Accepted: 4 February 2008 